\title{
O CASO DE ISRAEL: A TEORIA DO GOVERNO MISTO SOB A PERSPECTIVA DE NORBERTO BOBBIO
}

\section{THE CASE OF ISRAEL: THE THEORY OF GOVERNMENT MIXED UNDER THE PERSPECTIVE OF NORBERTO BOBBIO}

Fábio Metzger ${ }^{1}$

\begin{abstract}
RESUMO: O presente texto apresenta uma argumentaçăo sobre como a teoria do governo misto, desenvolvida originalmente por clássicos greco-romanos, e relida por Norberto Bobbio, se encaixa no caso de Israel, país que vive uma situaçăo limite, entre construir uma sociedade com identidade própria e ao mesmo tempo com algum grau de pluralismo, e manter um Estado em meio a vizinhos que possuem dificuldades de relacionamento político.
\end{abstract}

PALAVRAS-CHAVE: Israel; Estado; governo misto; política; governo.

ABSTRACT: This text presents an argument about as the theory of mixed government, originally developed by Greco-Roman classics, and re-read by Norberto Bobbio fits in the case of Israel, a country that lives in a limit situation, between building a society with its own identity and at the same time with some degree of pluralism, and to maintain a state among neighbors that have difficulties of political relationship.

KEYWORDS: Israel; State; mixed government; policy; government.

\section{INTRODUÇÃO}

Para se compreender Israel, é necessário ir além das aparências de noticiários, imagens televisivas, e buscar saber a respeito de uma série de nuances que fazem desse Estado um caso bem específico de análise institucional. Nem é o diabo que muitos desejam pintar. Tampouco é a visão idílica que outros desejam fazer reproduzir dos tempos antigos aos modernos, como se judeus dos tempos atuais pretendessem realmente se equivaler àqueles personagens que estão retratados nas Escrituras. Aqui, será analisado o caso israelense sob a perspectiva do filósofo jurídico-político Norberto Bobbio, que busca trabalhar com conceitos que dizem respeito a teorias de formas de governo, e como as práticas destes se dão, ordenamentos de normas jurídicas, e como os modelos modernos de Estados se comportam perante o que pensavam os antigos, a partir de conceitos como democracia, governo misto e outras definições $(2001 ; 2000 ; 1998 ; 1993 ; 1987)$.

É importante estar atento às definiçôes que sâo desenvolvidas por Bobbio dentro de seu pensamento, tanto o político, quanto o jurídico. No primeiro, prioriza mais as questóes das formas de como governos se desenvolvem, a maneira como eles se

Jornalista e doutor em Ciência Política pela FFLCH-USP 
organizam as suas instituiçóes básicas, e quais săo os regimes que acabam adotando. No segundo, Bobbio busca demonstrar que um sistema jurídico náo é outra coisa, se năo um edifício em que a estabilidade de leis deve manter certa coerência que, entretanto, nem sempre se verifica: existem conflitos entre leis, normas e resoluçôes internas, seja pelos critérios de tempo, local, instância ou hábito, que geram as anomalias do direito, as chamadas antinomias, que é em que o poder judiciário deve trabalhar, a fim de esclarecer qual das regras em conflito deve prevalecer (CARDOSO, 2011/2012, pp. 613-625; MOURA, 2009).

Sem desprezar, e muito pelo contrário, apoiando-se na moralidade universal de governos sob Estado democrático de direito e os direitos fundamentais da pessoa e da dignidade humanas, o pensamento bobbiano, por outro lado, sustenta-se a partir de um forte realismo em relaçấo ao modo em que săo construídos os Estados nacionais e os seus ordenamentos de leis. Nesse sentido, a definiçâo de um Estado laico pode ser uma referência. No entanto, é possível observar nas análises que săo bobbianas outras nuances, a partir das definiçôes originais de Kelsen (1992): o Estado pode ser laico formalmente, mas qual é a sua relaçăo com a definiçăo de Estado de direito? Democrática (definida pela vontade popular) ${ }^{2}$ ou autocrática (definida segundo a vontade de seu próprio governante e daqueles que o sustentam) (KELSEN, 1992, pp. 292-295)? Ou seja: buscando a regra, ou aceitando as exceçóes? E dentro desse sentido: mesmo que um Estado nâo tenha em si a definiçấo formal do laicismo, é possível que exista prática democrática dentro dele? Que um ordenamento jurídico possibilite tais aberturas?

Aqui pode-se verificar a importância do pensamento bobbiano em relaçâo às formas de governo que cada país pode adotar. De maneira que possa existir, com todas as imperfeiçôes internas da estrutura jurídica, a possibilidade de debates dentro de uma sociedade civil. A partir de uma sociedade civil forte, é que se faz possível verificar o avanço e a evoluçăo dos direitos de um corpo social rumo à ideia de democracia.

E aqui pode-se verificar algumas limitaçōes que se encontram, nâo apenas no pensamento jurídico de cada Estado, mas também na relaçâo entre eles, muitas de conflito, podendo chegar à situaçăo de guerra, dependendo do nível de tensâo. Por essa visấo, tem-se aqui o Estado de Israel. Trata-se de um caso no qual governo e Estado estâo sob tensâo interna. De um lado, esse governo busca, dentro do que Bobbio entende ser um sistema político liberal, com perspectiva democrática: há revezamento de partidos políticos no poder, arranjos e coalizōes governamentais, eleiçóes gerais e abertas acontecendo regularmente, situaçăo e oposiçăo em debate amplo, etc. Por outro, por Israel ter seu posicionamento e as suas características em situaçăo de tensâo com os seus vizinhos, possui a tendência à militarizaçăo de seu Estado, o que influi diretamente no funcionamento de suas instituiçóes.

Essa dicotomia pode levar a um grande desconforto dentro do debate em geral e do acadêmico em particular acerca de como é possível pensar questôes de democracia diante do militarismo. É possível questionar se a moral de uma sociedade

Nas palavras de Bobbio, democracia é o governo de todos, em contraposiçáo ao governo de uns poucos (1987, p. 31). Desse ponto de vista, pensando em Bobbio (1987) e Kelsen (1992), o governo de uns poucos pode ser classificado como autocracia. 
pode ser violada, corrompida devido a uma situaçăo de guerra, de modo aos valores democráticos serem, enfim derrotados, tanto interna, quanto externamente, se houver uma diáspora, em pensando Israel como Estado judeu, por exemplo. E aqui podemos imaginar que a definiçăo de moral religiosa possa ser colocada em questâo.

Começamos com uma provocaçâo feita a Bobbio, por um participante de um evento na Universidade de Brasília (UnB), em 1983:

\begin{abstract}
Pergunta: Quando se fala de moral judaico-cristă, quer-se referir à ética da virtude e nâo à ética finalística, maquiavélica. Como explicar entáo o apoio quase geral da comunidade judaica internacional à guerra no Líbano, a qual viola todos os critérios de moralidade na guerra, mencionados no seu livro [O problema da guerra e as vias da paz] comentando anteontem? Bobbio: Falei de moral cristá e aqui se fala de comunidade judaica. Parece que săo coisa completamente diversas. A comunidade judaica internacional é uma comunidade política com interesses políticos. Năo vejo como se possa pôr em discussăo o problema da moral cristă em relaçăo à comunidade judaica. A comunidade judaica assumiu determinadas atitudes políticas que se podem aprovar ou năo, mas năo criam qualquer crise para a moral cristă ou para a moral universal. Sobretudo năo toca ao assunto de que tratei, que é o problema da moral universal e da política. Posso também acrescentar, a título de esclarecimento, que a ideia de uma derrogaçăo da lei moral é tratada também pelos teólogos. Há teólogos que sustentaram a tese da guerra justa. Nâo condenaram todas as guerras. Afirmaram que existem guerras justas. Guerras justas săo, por exemplo, as guerras de defesa. Se alguém interpretar a guerra de Israel como uma guerra de defesa, poderá considerá-la uma guerra justa. Na realidade, o caso concreto náo parecer pertencer à questăo geral de que tratei. (BOBBIO, 2001, pp. 97-114)
\end{abstract}

É interessante que a pessoa que perguntou imaginou algumas questóes em relaçăo ao direito de guerra, em face à moral religiosa. Pode-se negar tal pergunta? Sim, há conceitos que pertencem ao direito e à política. E há definiçôes que estâo na moral. Desse ponto de vista, pode-se compreender o questionamento a Bobbio sob o ponto de vista de uma abordagem que poderia ser pensada da seguinte maneira: se, a partir de uma moral judaico-cristă, as regras de guerra estăo sendo fortemente violadas, é possível pensar de que forma uma pessoa de determinada confissăo pensa democraticamente? Se partirmos do princípio que essa pergunta é feita no Brasil, bem provavelmente terá sido de uma pessoa que vivencia valores cristăos dentro de sua sociedade. De maneira que, se é possível pensar como um democrata cristâo para os países ocidentais, por que năo Israel e a comunidade judaica pensarem enquanto democratas judaicos?

Nesse ponto, Bobbio buscou definir algumas diferenças. Uma coisa é o judaísmo em si; e aqui é possível falar da moral religiosa: é possível ter uma moral judaica, e outra cristă, oriunda do judaísmo antigo. Outra é a comunidade judaica, atuando internacionalmente, com os seus interesses; e, nesse caso, está-se falando a respeito da política, e as suas implicaçôes, que nem sempre coincidem com a moral, seja ela religiosa, ou entăo laica, democrática, etc. E, quando se trata de assuntos de guerra, mesmo a moral cristă (e o direito internacional) dăo a possibilidade de pensar as "guerras justas", ${ }^{3}$ enquanto forma de defesa de um país ou povo. Aqui, sem muito se

3 É possível questionar se uma guerra é justa ou nâo, dependendo do ponto de vista, obviamente. 
aprofundar, deixa claro é possível gostar ou năo do que Israel estava fazendo entâo no Líbano. No entanto, haveria a margem de se interpretar aquilo como uma forma de o Estado judeu estar se defendendo do que percebia enquanto uma ameaça existencial. Trata-se de uma questăo interessante notar, em tal caso, que a moralidade pode reprovar, sim (e nâo se trata de uma moralidade religiosa, e sim política). No entanto, o direito internacional náo é capaz de impedir que um Estado possa agir sobre outro unilateralmente. Condenaçóes internacionais e protestos podem criar constrangimentos, abalar a reputaçấo desse Estado. No entanto, por mais que tenha avançado, a política entre Estados soberanos ainda possui muito da correlaçăo de forças em que um Estado pode justificar para si e outros de maneira muito própria para atacar alguém que ele náo simpatiza (e/ou o provoca/ameaça). E isso dá muita margem para controvérsias.

Por se tratar de um Estado com muitas controvérsias, até mesmo internamente, Israel tem um caminho paradoxal em que atua entre diversos âmbitos identitários: o liberal, o democrático, o militarista e o confessional; de maneira que pode tanto abraçar a face mais universal de um judaísmo cosmopolita que a diáspora judaica abraça para si, como o contrário: convencer a diáspora, pelo medo dos eventos históricos que é melhor proteger-se e manter uma espécie de isolamento cultural que pode sustentar de maneira mais duradoura a história identitária particularista do povo judeu - o que, muitas vezes, contribui para acirrar os ânimos dentro do Oriente Médio. ${ }^{4}$

\section{AS AMBIGUIDADES DO ESTADO JUDEU}

Israel pode ser considerado um caso de Estado com características institucionais bastante específicas. Enquanto arranjo de organizaçôes estatais e de sociedade civil, carrega consigo diversas contradiçóes: de um lado, desenvolveu uma forte e vibrante sociedade civil, herdada principalmente da antiga diáspora espalhada por países europeus, americanos e outros continentes; de outro, ergueu uma estrutura na qual combina diversos arcabouços jurídicos que limitam a participaçăo de cidadâos năojudeus - apesar de tal participaçăo năo ser negada, tampouco impedida pelo país.

Essa estrutura define uma combinaçăo de Estado e governo na qual é preservado um conceito genérico estatal denominado "Estado judeu", que abrange diversas interpretaçóes possíveis do que isso possa significar. Certamente, năo contempla o conceito de república, pensado por Platăo em Atenas, e implementado originalmente, na antiga Roma pré-imperial. O que năo impede que possamos observar princípios republicanos operando dentro do funcionamento das instituiçōes israelenses. Pelo menos, no quesito que separa a noçâo do que é privado, e o que, sendo estatal, possa estar sendo aberto a qualquer cidadáo, nacional ou estrangeiro. Entretanto, tais princípios podem nâo ser totalmente operantes, quando a noçăo de Estado se restringe à ideia do adjetivo "judeu".

$4 \quad$ Ainda mais pelo fato de que os Estados e as populaçōes árabes, de maioria muçulmana, muitas vezes também vivem essa mesma questâo. Existe entre o universalismo que o Islá buscou estimular, desde a sua criaçáo, e o fundamentalismo uma tênue diferença, que pode transformar sociedades historicamente tolerantes em autoritárias. 
Qual seria o lugar do năo-judeu, especificamente o árabe-israelense, dentro dessa sociedade, sendo ele representante de cerca de $20 \%$ do total da populaçáo do país? Esse questionamento poderia minar qualquer ideia de republicanismo, em nome de uma etnia majoritária, em detrimento de outra, minoritária. Mas será que isso seria suficiente para decretar a ausência absoluta de republicanismo em Israel? Podemos aqui observar a existência, já considerada histórica, de repúblicas laicas de caráter nacional e/ou étnico derivadas da antiga URSS. Tais repúblicas năo estariam teoricamente discriminando populaçôes, mas sim especificando nacionalidades titulares, e outras participantes 5 . Dentro de tal definiçăo, a ideia de nacionalidade israelense ou de naçăo judaica (incluindo religiosos e năo-religiosos, crentes em um só Deus, ateus e outros) seria conferida a quem possuiria ao menos um avô ou avó judeu(ia); sendo levado em conta o direito de autodeterminaçăo do povo judeu, devido ao histórico de perseguiçōes, massacres, expurgos, conversôes forçadas e, no limite, genocídios que diminuíram o tamanho da populaçăo judaica.

Nesse sentido, pareceria ser suficiente o entendimento do significado de "ser judeu", apenas a partir de uma identidade, e desta, por meio de uma ligaçáo política com um Estado em determinado território. Por outro lado, é necessário notar uma questăo básica: como o judaísmo é uma religiăo sem hierarquia, qual seria o entendimento da porçăo mais religiosa, para năo dizer, da mais conservadora sobre o que é o judaísmo? Trata-se de uma identidade nacional apenas? Uma cultura milenar? Uma condiçâo, que levou a um grupo humano, a situaçôes-limites? Ou uma religiăo de compromisso com um testamento sob revelaçăo divina? Ou, entăo, a partir desta última definiçấo, um modo total de viver, para começar, religiâo, cultura, história e povo, e com isso, aí sim, toda a identidade?

Quando essa questăo mais profunda é colocada à tona, mais do que a ideia de nacionalidade, que poderia pressupor um Estado nacional com uma populaçáo titular específica, vem a possibilidade de formaçăo de um Estado religioso, no qual aqueles que săo mais aderentes aos princípios seriam mais contemplados que os demais, mesmo sendo todos pertencentes à ideia de judaísmo por si só. E, nesse sentido, Israel começa a ter limitaçôes maiores. Já havia limites na relaçăo da maioria de $80 \%$ judeus, perante os $20 \%$ árabes. Tais restriçóes ficam ainda maiores quando descobrimos

Aqui cabe alguns esclarecimentos: em primeiro lugar, poderá se questionar a origem dessas repúblicas, a partir da URSS, por terem sido impostas a partir de um Estado autoritário, no limite, totalitário. Por outro lado, a forma de definir nacionalidades já se dava na Rússia imperial, a partir da ideia, năo pelo direito de terra, e sim pelo de sangue. Algo que, em parte, Israel e países europeus acabam abraçando. Em segundo lugar, no caso da Rússia e adjacências (Ucrânia, Cazaquistăo, etc.), existe uma forma de identificaçăo que abarca bem mais uma identidade nacional do que a religiosa. Por exemplo: é possível uma pessoa ter origem judaica e fé muçulmana ou cristă (isso explica parte de muitos dos imigrantes russos de Israel náo serem, de fato, judeus). Ou o contrário, alguém uma nacionalidade específica (russa, ucraniana, etc.) e possuir fé judaica, muçulmana, etc. (adquirida por ascendentes, por exemplo). Em terceiro lugar: náo apenas na Rússia, como na Ucrânia, Belarus, Bálcâs, países bálticos, da Ásia Central, etc. foram criadas repúblicas ou províncias autônomas que definiam a titularidade nacional para cada uma dessas nacionalidades, mesmo depois do fim do socialismo real. E nesse sentido, nem todos os países se democratizaram, ou entáo se tornaram democracia total. Mesmo assim. Ainda é possível afirmar que estâo dentro de um caminho de ordenamento jurídico de longo, como outros países. Imaginemos a GrâBretanha hoje, e a do século XIX, sob o reinado da Rainha Vitória... E finalmente: na atual Federaçáo Russa existe uma Província Autônoma Judaica, na fronteira com a China, que um dia foi República Autônoma; curiosamente, os judeus sâo minoria de pouco mais de $1 \%$ da populaçấo, a despeito de ser considerados a nacionalidade titular... 
alguns aspectos adicionais: a) a impossibilidade de casamentos no civil em território israelense, devendo os casais celebrarem suas uniōes apenas no religioso o que faz com quem em relaçăo à maioria judaica, as minorias cristă e muçulmana tenham dificuldades em se integrar com o restante da populaçăo; b) leis que permitem com que serviços públicos deixem de funcionar nos dias de descanso (como o sábado), uma clara intervençâo do Estado, em benefício de quem pratica a religiăo judaica de maneira mais sistemática, e em detrimento aos demais; c) a possibilidade de dispensar ultra-ortodoxos do serviço militar, enquanto os demais cidadáos de origem judaica terăo dois anos (para mulheres) e três (para homens) que realizar duro e intensivo treinamento; d) ao mesmo tempo, ocorre a dispensa ao cidadăo árabe-israelense, que ao contrário do ultra-ortodoxo (cuja integraçâo está justamente em servir à fé do país, ficando em uma posiçăo bem destacada para si), estará entrando no mercado de trabalho e na universidade concorrendo com israelenses que tiveram dois ou três anos no serviço onde, năo apenas treinaram, como também tiveram estudos muitos mais aprofundados sobre como funciona a sociedade e o Estado israelenses.

Năo se deve deixar de levar em conta algumas outras realidades, que estăo mais ligadas ao cotidiano das respectivas comunidades e à orientaçăo do poder executivo israelense do que às leis em si mesmas; assim, a combinaçâo de uma taxa de natalidade alta, e uma destinaçấo de verbas para as regiōes no norte do país, onde mais se concentram, gera uma realidade na qual o árabe-israelense tende a ter menos oportunidades que um judeu de ser contemplado com os benefícios do bem-estar social. Ao mesmo tempo, o crescimento de verbas para fundaçóes ligadas a partidos políticos religiosos judaicos sustentam a possibilidade de quem for judeu praticante (mesmo nâo sendo ultra-ortodoxo) de ter oportunidades dentro do país.

\section{CARACTERÍSTICAS DE ISRAEL, ENQUANTO ESTADO E SOCIEDADE PLURALISTA}

Isso se faz suficiente para afirmar que Israel é um Estado sem pluralismo? Certamente, săo fatores limitadores. No entanto, antes de falar a respeito de Israel, é necessário compreender como foi o processo de unificaçăo das principais e hegemônicas correntes dentro do judaísmo moderno, a partir do século XIX. O nacionalismo judaico, em si, năo imaginou necessariamente a construçăo de um Estado. Havia uma série de preocupaçôes no que diz respeito à sobrevivência do povo judeu. Alguns dos movimentos estavam reivindicando apenas autonomia nacional (o autonomismo): ou seja, sustentar uma nacionalidade judaica dentro de outras naçōes maiores. Outros, um retorno espiritual à terra original de Sion (ou Ysrael), sem ter pensado na ideia de um Estado judeu. Ainda havia a ideia, que foi pensada justamente pelo fundador do movimento sionista, Theodor Herzl, de fundar um Estado judeu sem necessariamente ser na Terra de Israel (Eretz Yisrael). Quando esse grande movimento foi se desenvolvendo ao longo do século XX, existia uma série de grupos sociais e políticos. Por exemplo, entre os judeus da Europa Oriental, um partido de inspiraçáo socialista e sindicalista, o Bund, que defendia a nacionalidade judaica, sem pensar em um projeto de Estado. Sua prioridade era defender a nacionalidade judaica dentro de um ambiente (Lituânia, Rússia e Polônia) onde o antissemitismo crescia de forma cada vez maior. E, é claro, o próprio sionismo, que foi tomando corpo e forma, enquanto 
movimento de reivindicaçăo e autodeterminaçăo do povo judeu na primeira metade do século XX (PINSKY, 1978).

O sionismo, ele mesmo, tinha uma série de vertentes, que foi se desenvolvendo: vertentes que focavam mais a imigraçăo à Palestina/Israel, e posteriormente; que focavam a busca de uma emancipaçăo da comunidade judaica presente na regiâo; e as que reivindicavam mais concretamente um Estado independente. Até que o sionismo político (que reivindicava um Estado independente na regiăo) assumisse a hegemonia dentro do movimento sionista, e de lá para a própria comunidade judaica, ocorreu uma série de eventos históricos, especialmente entre a Primeira e a Segunda Guerra Mundiais.

Nesse contexto, ocorreu um processo de aproximaçăo entre as diversas comunidades judaicas pelo mundo, até que uma representaçăo mundial foi consolidada: o Congresso Judaico Mundial (CJM), que foi formalmente fundado em 1936, em Genebra, na Suíça (GOLDMANN, 1984, p. 46), justamente no momento em que o nazismo começava a sua escalada na Europa, e a Palestina vivia em uma situaçấo na qual árabes e judeus começavam a ter crescentes tensôes, diante do colonizador britânico. O sionismo, projeto político que serviu como uma fundamental referência para a formaçáo do Estado de Israel, se desenvolvia entre as demais alternativas nesse processo de unificaçăo dos judeus modernos, que buscavam unidade política mínima, diante da terrível realidade da escalada do antissemitismo, especialmente na Europa. Com o final da Segunda Guerra Mundial, e a revelaçăo sobre os acontecimentos da Shoah (Holocausto), iniciou-se uma intensa busca política por dois objetivos: políticas indenizatórias por parte da Alemanha, e a criaçăo de Israel, em negociaçóes extremamente delicadas, onde uma série de nuances entre os principais artífices defensores do CJM fizeram intenso trabalho de convencimento em que, a princípio parte considerável de diplomatas e governantes eram contrários (GOLDMANN, 1984, pp. 85-106).

O que interessa aqui é compreender como uma grande pluralidade de comunidades com hábitos e costumes tăo dispersos, tendo o judaísmo (identitário, cultural e/ ou religioso) como única forma de uniâo geral, foi capaz de se articular em um território e fundar nele um Estado. E, nesse sentido, năo necessariamente por uma questăo de valores, mas essencialmente por necessidade, o Congresso Judaico Mundial teve que ser construído a partir das pluralidades dessas várias formas de judaísmo, tendo como pano de fundo o drama da sobrevivência do povo judeu como motivador central. O CJM, que mais tarde passou a ter sede central em Nova Iorque (EUA), náo reunia necessariamente todos os judeus, mas a sua maioria, enquanto representaçăo (GOLDMANN, 1984, p. 43). Levando em conta que o judaísmo năo é uma religiâo que funciona como uma entidade fechada, tampouco possui hierarquia, foi por essa reuniâo de maiorias plurais entre si, que foram capazes de criar uma hegemonia que fosse capaz de dar voz a uma coletividade em nível mundial.

$E$, se essa hegemonia foi mundializada, por que năo poderia ser reproduzida a partir de um Estado territorial soberano? E aqui podemos observar que o Estado israelense foi construído transplantando algumas estruturas políticas do Ocidente para o Oriente, através da pluralidade das comunidades israelitas pelo mundo. Ao mesmo tempo, foi erguido dentro de um território que já possuía um arcabouço de três direitos: a lei comum britânica, as antigas leis otomanas, e, diante dos muçulmanos 
praticantes, a sharia. $O$ processo de construçăo do Estado judeu se deu enquanto resultado do desenvolvendo em, ao menos, meio século de uma sociedade civil judaica local (o ishuv), que construída cidades, comunidades agrícolas (kibutzim, moshavim, etc.), fábricas, universidades, escolas, além da difusăo do idioma hebraico, que passou a ser revivido a partir do século XIX. A grande quantidade de judeus vindos, inicialmente da Rússia, mas depois da Polônia, Alemanha e outras localidades, foi criando a necessidade de criar instituiçôes plurais. Mais tarde, com a vinda de árabes, muitos saídos, outros expulsos, após Israel ter sido criado, a variedade de judeus foi se tornando ainda maior. ${ }^{6}$ Incluindo a populaçăo árabe cristă, muçulmana e druza, ainda que Israel possa se declarar Estado judeu, năo pode ignorar tal realidade. De maneira que o árabe, por exemplo, é também considerado idioma oficial, junto com o hebraico.

Esse pluriculturalismo, que foi estimulado de fora para dentro, e que dentro do próprio país também teve o seu estímulo, pode nâo ter criado um sistema laico, tal como, por exemplo, a França republicana. No entanto, há algumas semelhanças com o que foi sendo desenvolvido ao longo de séculos dentro da Gră-Bretanha. E aqui é preciso notar que Israel nâo buscou tanto focar a construçăo de seu aparato jurídico na normatividade constitucional que seria herdada do direito romano. Optou por uma abordagem mais empírica, próxima da vivência anglo-saxă, com adaptaçōes próprias da regiăo. Dentro desse ponto de vista, pode-se compreender Israel, como um fenômeno de construçăo institucional de um sistema liberal. E essa é uma outra questăo, na qual é necessário observar de que forma os instrumentos democráticos podem ser ora inibidos ora estimulados.

Em termos gerais, a democracia é o regime que expande os direitos políticos da populaçăo por meio do sufrágio universal. Por outro lado, o liberalismo expande os direitos civis dos indivíduos e limita o poder do Estado por meio do sufrágio restrito e do governo constitucional. O princípio da democracia pura, a vontade da maioria, pode prevalecer e, ao mesmo tempo, respeitar os direitos de cidadania (ou as liberdades individuais) inerentes às minorias dentro de uma sociedade. Por sua vez, um regime liberal pode garantir os direitos civis a todos os cidadâos, limitando, contudo, a uma minoria privilegiada a participaçăo na vida política do Estado. Sendo assim: "a democracia é antiga", e o "liberalismo é moderno" (BOBBIO, 1987, pp. 28-31). 0 Estado liberal como aquele que, em benefício das liberdades individuais, limita os seus próprios poderes, em contraste ao Estado máximo (ou absoluto), cujos poderes interferem na vida dos indivíduos. Esse Estado liberal é mínimo, no que diz respeito ao limite de seus próprios poderes, mas năo é ausente no que diz respeito a estabelecer a ordem social (BOBBIO, 1993; 1987).

Por esta observaçăo, pode-se observar que Israel construiu historicamente a sua sociedade, a partir de uma hegemonia plural, fazendo com que os grupos náo-hegemônicos tivessem que se integrar por baixo. Assim, a partir de 1948, árabes (que inicialmente, năo tinham nem direito de votar), conservadores, ${ }^{7}$ grupos judaicos

\footnotetext{
$6 \quad$ Se colocarmos que tivemos também judeus vindos dos EUA, América Latina, Etiópia, Rússia soviética, e até mesmo do Extremo Oriente, imagine a quantidade de variaçōes culturais existentes dentro de uma sociedade como essa.

7 Curiosamente, sionistas socialistas, liberais e sionistas políticos progressistas săo quem forjou a primeira hegemonia em Israel. Os conservadores e nacionalistas ficaram em posiçáo de desvantagem, apesar de terem tentados por meios extra-eleitorais alcançar alguns de seus objetivos.
} 
năo-sionistas ou até mesmo antissionistas tinham que se adaptar à nova realidade, em situaçăo de participaçăo política năo central. Essa hegemonia, ao longo de quase três décadas, a partir do primeiro governo do partido direitista Likud, em 1977, foi se modificando: uma direita nacionalista e conservadora (o sionismo revisionista, defensor da Grande Israel) foi crescendo, a participaçăo de grupos sionistas religiosos na política também teve uma grande escalada (defensores da Israel bíblica), isolando o grupo anterior; este, representado pelo sionismo político, a despeito de ter consigo um discurso com forte teor nacionalista e religioso, tinha uma posição mais pragmática: sabia da necessidade em ter que fazer um acordo de paz com os países árabes, e o preço disso seria, entre outras concessóes, a criaçáo do Estado da Palestina, ao lado de Israel. Por outro lado, os representantes originais do sionismo socialista, já estavam cada vez mais isolados do Mainstream israelense, e depois judaico, com a escalada da Guerra Fria.

Em observando os reflexos de tamanhas mudanças, é possível verificar que o sistema eleitoral israelense tem uma grande quantidade de partidos e listas partidárias competindo entre si, e ao mesmo tempo buscando fidelizar espaços de eleitorados que se excluem mutuamente dentro da sociedade civil. Ao mesmo tempo, há diversas situaçōes de mudanças de conjuntura, em que o cidadáo israelense médio (sabra) que foi se integrando na dinâmica política, ao longo de cerca de meio século, passou a ter um comportamento, menos de fidelizaçâo partidária, e mais de escolher a melhor opçâo que possa atender aos seus anseios individuais, tal como qualquer sociedade democrática ocidental ${ }^{8}$. E, nesse sentido, existe rodízio de governantes, apesar de, nos últimos anos, Benjamin Netanyahu ter se consolidado como primeiro-ministro, de forma a sustentar um grupo fortemente hegemônico no poder. Por outro lado, há oposiçấo ativa a este governo, liderada, por parte dos mais moderados, ao Partido Trabalhista, os pacifistas do Meretz, e a Lista Compartilhada majoritariamente representada por eleitores e políticos árabes. É interessante notar que, além de deputados, existe em Israel embaixadores árabes, inclusive muçulmanos, além de prefeitos (especialmente na regiăo norte do país) e um Juiz na Suprema Corte. Já existiu ministro árabe em recente governo israelense. $O$ árabe é reconhecido como língua oficial. De modo que, do ponto de vista formal, năo dá para simplesmente afirmar que Israel nega a possibilidade de participaçaao da populaçăo árabe, apesar de ser possível notar mecanismos que a subestime, seja pela via nacional-identitária, ou entáo pela via religiosa.

Há sim, conferindo o funcionamento do parlamento israelense (Knesset), forte noçấo de uma estrutura democrático-liberal, assemelhada à da Gră-Bretanha: a ausência de uma constituiçâo escrita, mas a presença de algumas leis básicas e uma lei fundamental. Por outro lado, diferente do que acontece na Gră-Bretanha, que se construiu ao longo de mais de um milênio de leis consuetudinárias (derivadas de costumes). No caso do direito israelense, é preciso levar em conta que năo se trata de um edifício jurídico antigo, e sim recente, herdando de si antigas leis do Império Otomano e do mandato britânico da Palestina, combinados com a lei que foi sendo desenvolvida dentro do Estado de Israel - no caso dos territórios ocupados da Cisjordânia,

8 E, nesse sentido, nâo dá para descartar a grande questăo que é, afinal, de natureza coletiva: vale à pena fazer a paz com os países árabes? 
Israel combina as leis otomanas e britânicas, com uma legislaçăo de administraçâo militar, onde os palestinos sustentam nas áreas em que mantêm autonomia as suas leis específicas.

\section{ISRAEL E AS SUAS FORÇAS ARMADAS}

Como se viu ao longo do trabalho, os espaços de privaçăo de liberdade sâo espaços de negaçấo de aspectos multiculturais.

Aliás, a presença das Forças Armadas na sociedade israelense é outro tema que năo deve passar batido aqui. Esse é outro elemento limitador. Sempre que uma organizaçăo militar é central na forma de organizar uma sociedade, assiste-se a um fator limitador dentro do conceito de pluralismo político. Uma vez que as Forças Armadas sâo instituiçôes que zelam, antes de quaisquer governos, pelo Estado. Em um governo de alto grau de democracia, as Forças Armadas buscam se manter o máximo distantes da possibilidade de intervir dentro dos governos eleitos, e da sociedade civil, atuando apenas pontualmente, e se convocadas. Já em sociedades autoritárias, as Forças Armadas tendem a se tornar constantes, dependendo de como o governo e o Estado săo organizados. Se o regime se apresenta como autocrático, săo grandes as possibilidades de um aparato policial operar, interferindo de maneira ostensiva dentro da sociedade civil, e se entrelaçando com instituiçôes governamentais. Nesse caso, fica a questăo: onde e quando atua a mâo forte do Estado; e quando e onde opera o governo enquanto representante de uma naçăo, dentro de um tempo e espaço específicos?

Por sua natureza, quaisquer Forças Armadas prezam a disciplina, e punem implacavelmente aquilo que entendem como questionamento ou insubordinaçáo. A hierarquia é o ponto central dessas organizaçôes, e ainda que aqueles que ocupem cargos superiores estejam sujeitos a cometer erros, os questionamentos em geral săo limitados. Em se pensando que a estrutura das Forças Armadas de qualquer país coloque a defesa do Estado como prioridade (enquanto os governos săo assuntos de civis), há que se buscar compreender o grau de interaçăo e integraçăo de Estado e governo de cada caso. Até porque há sociedades nas quais a separaçăo entre e governo é mais clara, e em que civis possuem mais força. E há outras em que essa distinçâo é pouco notada, e as Forças Armadas têm maior presença. Por lado, há um fator que deve ser levado em conta: um país pode năo ser exatamente democrático nas suas formas de governo, mas năo necessariamente ter que conviver com um pesado um aparato policial (algumas monarquias tradicionais de pequenos Estados modernos podem servir de exemplo). Mas também há a possibilidade de um país ter regras democráticas. No entanto, ter as Forças Armadas como enquanto conjunto institucional que condiciona toda uma sociedade civil.

O caso de Israel se encaixa nesta última probabilidade. E isso năo se dá porque os israelenses săo mais brutais que outras populaçōes, porque sejam opressores por natureza ou devido a qualquer outro desvio de conduta humana. Tais comportamentos poderiam ser observados em outras populaçōes vivendo situaçóes semelhantes. Obviamente aqui é necessário observar uma realidade: o acúmulo histórico de judeus de diversas partes do mundo encontrando-se, e compartilhando diversas experiências traumáticas. Seria fator suficiente para agirem como agem? Năo dá para conjecturar por apenas essa constataçăo. Obviamente, é necessário observar a forma como 
Israel foi fundada, e como os seus vizinhos reagiram; como a retórica de lado a lado se radicalizou; e como o desejo mútuo de sabotagem, expulsâo ou destruiçáo de árabes e judeus cresceu em uma espiral política que muito tem a ver com a geopolítica internacional.

Sendo Israel, um país com duas frentes territoriais para defender, com populaçấo de 8 milhóes de habitantes em cerca de 20.000 quilômetros quadrados, diante do mundo árabe, com mais de 20 países, somando cerca de 300 milhóes de habitantes, em 10 milhôes de quilômetros quadrados, é possível pressupor que há uma grande assimetria, do Estado judeu em relaçăo aos seus vizinhos. Levando em conta que Israel só possui relaçóes diplomáticas com apenas dois desses Estados (Egito e Jordânia), e ainda assim de forma muito fria, é possível notar que há um forte clima de hostilidade; por outro lado, vivendo em área comum (entre o Rio Jordăo e o Mediterrâneo, uma área de cerca de 27.000 quilômetros quadrados), e possuindo legitimidade internacional para a proclamaçăo de independência, o povo árabe palestino, por meio de suas autoridades reconhecidas (OLP, ANP), reivindica o seu Estado nacional, na área em que é majoritário. Há, entretanto, reivindicaçōes por parte dos palestinos que geram desconfianças entre os israelenses: o direito de retorno dos refugiados que saíram de suas casas quando Israel foi fundada em 1948, e depois - algo que gera entre a populaçăo israelense o temor de, dada tal possibilidade, de perder a condiçấo de maioria demográfica, e assim, correr o risco de perder o controle de seu Estado. Por outro lado, a própria criaçâo do Estado da Palestina nos territórios que estăo sob ocupaçăo (Cisjordânia) ou bloqueio (Gaza) geram também temores aos israelenses de passar a ter um Estado com pouca profundidade territorial (em alguns locais, áreas densamente povoadas com menos de 16 quilômetros de largura). Já existe na regiâo grupos políticos declaradamente inimigos de Israel, e alguns formando milícias fortemente armadas, como é o caso do Hezbollah, representando a populaçâo xiita do sul do Líbano. Por outro lado, uma potência média regional (que nâo é de origem árabe, e sim persa), o Irâ (país com quase 2 milhôes de quilômetros quadrados e mais de 80 milhóes de habitantes, um dos maiores produtores e exportadores de petróleo e gás natural), declarou-se diversas vezes inimigo do Estado judeu, manifestou o desejo de riscar Israel do mapa, e teve algumas de suas lideranças (inclusive um ex-presidente) que o Holocausto seria um "mito".

Diante de tantas realidades que săo desfavoráveis na geopolítica, Israel busca minimizar suas desvantagens com alianças articuladas com países europeus (especialmente a Alemanha) e principalmente com os EUA. Mas, para tanto, a sua açăo só se torna efetiva, na medida em que mobiliza da forma mais totalizante sua populaçăo dentro de suas Forças Armadas. Em um grau năo observado em outros países. Dificilmente, um israelense judeu náo ortodoxo escapa do serviço militar que dura três anos para homens, e dois para as mulheres. Os efetivos permanentes podem náo passar dos 300.000. Mas em até 48 horas é capaz de mobilizar mais de 1 milhâo de reservistas com experiência e capacidade de luta superior à da grande maioria dos exércitos permanentes mundiais. Guerras como a de 1967 e a de 1973 envolveram grandes parcelas da populaçăo israelense diretamente no confronto. A possibilidade de uma escalada, mesmo sendo remota, nunca deixa de ser descartada, principalmente quando começam os confrontos (assimétricos, certamente) contra grupos paramilitares e terroristas. 
Nesse sentido, desde os anos 1960, observa-se a constância de diversos primeiros-ministros israelenses que eram oficiais do Exército: Levy Eshkol, Itzhak Rabin, Shimon Peres, Ehud Barak, Ariel Sharon, todos esses com a patente de general, além de Binjamin Netanianhu, que chegou a capităo. Tamanha militarizaçăo condiciona os diversos gabinetes israelenses: as políticas de governo, assim como as de Estado săo sempre atreladas de maneira forte, ainda mais quando as rivalidades com os vizinhos e o Iră crescem. E aqui, há que se observar um aspecto: Israel nasceu como uma variante de Estado com elementos socialistas, em 1948, tendo inclusive, curiosamente, um apoio político maior da URSS do que de seu atual maior aliado, os EUA. Desde a guerra de 1967, no entanto, o posicionamento definitivo de Israel ao lado dos norte-americanos foi empurrando o país cada vez mais para a direita. E, com o fim da URSS, para uma direita cada vez mais linha-dura.

Assim, foi se formando uma espécie de hegemonia interna que passou a ser composta por: 1) grupos religiosos judaicos militantes, observando de maneira mais firme o caráter judeu do Estado; 2) grupos nacionalistas, em uma defesa cada vez mais tenaz do Exército, enquanto fiador de Israel, mais enquanto terra do que da populaçăo judaica majoritária em seu respectivo território; 3) grupos simultaneamente nacionalistas e religiosos, que buscam, a hegemonia da "Grande Israel", seja pela justificativa bíblica, ou entâo pela defesa geopolítica.

Esses grupos que compóem a hegemonia política israelense seguem a continuaçâo da ideia de judaísmo religioso, e das Forças Armadas como formas institucionais de organizar uma sociedade. Em termos normativos, quando uma religiăo se sobrepóe às demais, isso enfraquece a ideia de democracia. Quando as Forças Armadas se elevam em relaçăo à sociedade civil, e sobre ela influenciam o seu dia-a-dia, esse também é um elemento enfraquecedor. Nesse sentido, quando buscam (dentro do que lhes cabe) adiar a possibilidade da proclamaçăo do Estado da Palestina, intensificar as colonizaçóes de judeus na Cisjordânia, e intensificar, em determinados momentos, o bloqueio a Gaza, Israel passa uma mensagem que dá a impressăo a outros atores globais e regionais de náo estabelecer fronteiras entre o que é o seu governo e o que significa a responsabilidade de governar outra populaçăo.

Nâo seria problemático estabelecer Israel enquanto Estado judeu (há diversos outros países em situaçăo semelhante, que se declaram Estados confessionais, ou seja, possuem religióes oficiais), e pode ser perfeitamente compreensível a militarizaçâo do país, em se levando em conta que as fronteiras estivessem definidas, e a própria populaçăo pudesse assim definir que essa seria a sua forma de organizaçấo, estando os palestinos submetidos a outro conjunto de regras. No entanto, săo questóes que a própria sociedade israelense ainda nấo conseguiu definir dentro de si mesma, e em relaçâo aos vizinhos palestinos.

\section{PENSANDO ISRAEL CONCEITUALMENTE}

Isso torna Israel algo como uma ditadura, um despotismo, uma autocracia? É necessário, antes de responder, compreender que a populaçăo israelense leva consigo, também de maneira hegemônica, valores democráticos de outras experiências nas Américas e Europa. Assim, por mais que se afirme que os modos militaristas e 
religiosos sejam limitadores, náo dá para negar que, naquela regiăo fronteiriça interna onde é internacionalmente reconhecido Israel, exista uma sociedade que debate, possui extremos que divergem publicamente, que coexistem, apesar das enormes diferenças entre si, etc.

Ocorre que aqui, pode-se pensar em instituiçóes que se entrelaçam e misturam as suas formas de ser e agir, a partir de formas mistas de governo. Em se levando em conta que o confessionalismo dá margem a um avanço de grupos teocráticos, fica difícil dizer que eles săo ausentes dentro de Israel. A própria estrutura do país tem uma característica interessante: năo existe o presidente da república, mas sim do sinédrio. $O$ sinédrio é uma instituiçâo reconstruída formalmente, herdada do velho Supremo Conselho dos Sábios que comandavam as antigas monarquias israelitas. Obviamente, é uma instituiçâo hoje secularizada. No entanto, fica aqui a curiosidade de uma ambivalência. Por outro lado, Israel possui dois grăo-rabinos para responsabilizar-se sobre questóes religiosas dentro do Estado, um para os descendentes dos judeus europeus (ashkenazim), outro de judeus árabes e mediterrâneos (sefaradim). Eles năo teriam nenhum poder equivalente ao de um aiatolá no Irâ, por exemplo, cujos poderes temporal e espiritual concentram-se em suas măos. Mas podem ter forte influência nas populaçōes religiosas do país, tal como o mufti do Cairo para os muçulmanos do Egito. Além disso, o fato de Israel năo possuir uma constituiçăo escrita dá a margem para que o direito religioso judaico (a halachá, tal como a sharia, no Islâ) possa ser aceito, especialmente quando se trata de um embate intra-religioso. Isso cria uma espécie de governo com força própria em que os religiosos possuem a priori uma inserçăo. Estăo fortemente representados, a partir dessas instituiçóes, podendo se expandir da sociedade religiosa para a civil.

Por outro lado, as Forças Armadas, por sua própria natureza, representam uma forma de organizaçăo que busca evitar abrir debates. Seu funcionamento é realizado de maneira centralizada, de cima para baixo. Ou seja, um governo de quem comanda para quem é comandado. O outro nome para tal forma de governar é autocracia. Esse estilo de administraçăo também coloca os principais comandantes em uma situaçáo de forte exposiçăo. Ou acertam, e se tornam permanentemente reconhecidos. Ou erram estrondosamente, e aí săo fortemente censurados e punidos. A sociedade militar, nesse sentido, ainda que busque se preservar internamente, no caso de Israel, acaba criando fortes vínculos com a sociedade civil.

E, nesse caso, a sociedade civil sempre vive sob a pressăo da possibilidade de leis religiosas e decisóes militares, que podem criar exceçôes. No caso das decisôes militares, isso é compreendido dentro de um âmbito de hostilidades externas. Já na questăo religiosa, isso se dá em um aspecto que pode tanto ser intrassocial (religiosos, leigos, laicos e pertencentes a outra fé), como extrassocial (vizinhos que também consagram Estados confessionais e militarizados, com outra religiăo, e identidades nacionais mutuamente excludentes em relaçâo a Israel). De maneira que o funcionamento institucional israelense mais democrático sofre diversas interferências no modo de ele se moldar. Nâo é autocrático, nâo é teocrático. É uma forma mista de governar, combinando elementos verdadeiramente liberais, com outros nacionalistas e religiosos, dentro de um pequeno território densamente povoado. 


\section{SOBRE O CONCEITO DE GOVERNO MISTO}

Quando Bobbio (1998) escreveu sobre as diversas formas de governo, diferenciou os diversos regimes: se săo monarquias ou repúblicas, se as monarquias săo constitucionais ou absolutas, se as repúblicas sâo de regime presidencialista ou parlamentarista, e assim por diante. Levava consigo também a tradiçăo de Kelsen (1992): qual regime pode ser considerado democrático? E qual autocrático? Dentre esses dois extremos, em que o liberalismo, forma moderna de governo, entra de maneira a ser um organizador dentro do longo ciclo modernizador dos Estados territoriais?

Nesse sentido, Bobbio buscou fazer um apanhado dos mais variados pensadores políticos e as suas contribuiçóes dentro de uma teoria geral da política (Bobbio, 2000). No caso, ele estava buscando organizar textos de pensadores especialmente modernos, e as suas liçóes no que diz respeito à partiçăo de poderes (Montesquieu, os federalistas dos EUA), liberdade e liberalismo (Locke, Tocqueville), formaçâo do Estado (Maquiavel, Hobbes), sua normatividade, representatividade (Rousseau, Kant), e assim por diante.

Se formos analisar, as teorias das formas de governo e da política de Bobbio (2000; 1998) convergem para os clássicos, nos quais se faz necessário verificar a origem de boa parte da evoluçấo da estrutura das práxis, do pensamento e da estrutura política que temos hoje. Nesse sentido, o tema a respeito das boas e más formas de governo ganha um lugar especial. Antes de qualquer leitura que possamos sobre os termos democracia, autocracia ou liberalismo, que foram desenvolvidos especialmente para os tempos atuais, é preciso retornar a alguns dos clássicos da política a respeito das boas e más formas de governo, pensando-as no contexto dos atuais Estados modernos. Essa busca Bobbio (1998) procura fazer associando o pensamento dos antigos gregos como Aristóteles e Políbio, e renascentistas como Maquiavel, que buscaram pensar de que maneira formas de governos puros (monárquicos, elitistas ou populares) poderiam se degenerar, pelos mais variados motivos. Todos eles buscavam uma soluçâo. Inicialmente, Aristóteles imaginou um meio termo que pudesse contemplar algumas das boas e más formas de governos, buscando aquilo que ele denominava "mediana". Assim, as formas puras de bons governos eram classificadas por Aristóteles como monarquia (de um só), aristocracia (para poucos) e a politia (para muitos), em nome do interesse comum da polis; em contraponto, respectivamente à tirania, à oligarquia e à democracia, onde prevalece o interesse privado (BOBBIO, 1998, pp. 55-57). Para Aristóteles, o melhor governo é aquele comandado pelo menor número de governantes; e a democracia como a menos ruim forma de mau governo (ARISTÓTELES, 2004, pp. 226-230). Nesse sentido, a "mediana" entre monarquia e democracia seria a melhor forma mista de governo que, se năo era perfeita, ao menos buscava minimizar as falhas da alta representaçăo democrática, com o comando de um bom monarca. Buscando se aproximar do conceito de politia, sem necessariamente ser monárquico, aristocrático (ou oligárquico), ou democrático, e combinando o melhor de cada uma dessas formas de governo (BOBBIO, 1998, pp. 58-61).

Ainda năo estava exatamente bem definido o conceito de governo misto. Foi preciso que o historiador ateniense que se tornou cidadāo romano Políbio desenvolvesse uma segunda leitura a respeito do tema, com a seguinte questăo: como Roma 
foi capaz de expandir tăo rapidamente o seu império (em cerca de 53 anos) (POLÍBIO, 1996)? Nesse caso, as boas formas de governo săo: o reino (para um só) aristocracia (poucos) e democracia (muitos). ${ }^{9}$ Enquanto as más formas de governo seriam a tirania (para um só), a oligarquia (poucos), e a oclocracia10 (muitos) (POLÍBIO, 1996, pp. 326-332). Ele conclui que a melhor forma de governo é aquela que preserva as melhores características de cada um dos governos (reino, aristocracia e democracia), de maneira que se mantenha um equilíbrio. Esse fator - o equilíbrio - é a fonte que mantém a estabilidade interna para que um país possa avançar sobre os seus adversários (BOBBIO, 1988, pp. 70-71). Que é o que Políbio denomina governo misto enquanto forma mais estável, que encerrasse um ciclo de mudanças de formas de governos puros sujeitos à degeneraçâo (POLÍBIO, 1996, p. 348). Assim, a res publica (república, ou coisa de todos) seria a modalidade mais avançada: com a combinaçáo do governo de um só (o antigo Consulado representando o Estado), de poucos (o Senado Romano, representando a elite) e muitos (a Assembleia, representando a populaçâo livre). Essa combinaçâo permitiu a estabilidade política romana, de maneira que os conflitos internos fossem filtrados para as instituiçōes, e com isso as formas mais radicais de manifestaçôes dos estratos da sociedade năo descambassem para rupturas institucionais. O que permitiu, que Roma pudesse avançar sobre os demais países.

Aqui, vamos nos remeter a outro autor, desta vez, durante o Renascimento, Maquiavel (1994, p. 17) e os seus Discorsi, em que sâo descritos os mesmos ciclos de governos, de um, poucos e muitos em Roma, sucessivamente se degenerando e se sucedendo, tal como Políbio o fez, até que surgisse o governo misto, ou a república. Uma trajetória na qual a antiga classe monárquica (ou autocrática, utilizando aqui os termos modernos que Kelsen e o Bobbio utilizam) fundadora do Estado - teve os seus poderes limitados por um sistema aristocrático de senadores - que instituiu um regime com duas autoridades máximas - os cônsules. Um, derivado da classe monárquica, outro da aristocracia senatorial. Diante do crescimento da insatisfaçâo popular, foi necessária a criaçăo da tribuna popular (plebe), a fim de representar a populaçăo. A experiência que Maquiavel cita é a de Roma, enquanto um modelo misto, que combina o povo, a aristocracia e a monarquia (MAQUIAVEL, 1994, p. 20).

Os termos de Maquiavel săo semelhantes aos de seus antecessores, mas com algumas diferenças. As três formas puras de governo sâo: monarquia (de um só), aristocracia (poucos) e o Estado popular (muitos); em contraste com os maus governos: tirania, oligarquia e permissividade (ou anarquia). Fazendo a comparaçăo das boas e más formas de governos, Maquiavel conclui que a ideia de um governo misto seria a melhor, utilizando o exemplo romano, em que devido à experiência histórica, as classes sociais do Império (a dinastia fundadora, a aristocracia e o povo) foram sucessivamente assumindo o poder de todo o corpo político. E, uma vez que, com os governos puros de cada uma delas, era possível notar a tendência à piora em relaçâo ao todo, desenvolveu-se um arranjo institucional, no qual foi a luta delimitada dentro das instituiçóes, e nâo o equilíbrio de poderes entre os patrícios e plebeus, que permitiu o avanço romano. E neste ponto, Maquiavel fala a respeito de como isso

\footnotetext{
9 De maneira diversa do que Aristóteles denominava a politia.

10 O governo onde as paixôes das massas prevalecem, dando margem a lideranças aventureiras.
} 
foi fundamental no conceito de liberdade e levou a república romana à sua grandeza (MAQUIAVEL, 1994, pp. 18-22).

\section{0 GOVERNO MISTO ISRAELENSE}

Nesse sentido, Israel năo deve ser visto como um conceito de governo misto conforme os clássicos, mas sim perante a visăo moderna. A partir de suas ambivalências, em que busca se construir enquanto: a) estrutura liberal a fim de abraçar a maior quantidade possível de correntes internas, ou seja, trata-se do liberalismo dos modernos, acomodando a democracia dos antigos; b) carregando consigo o nacionalismo judaico em sua versăo sionista política, e, a partir daí, construindo um Estado que defende o seu território, por meio de suas Forças Armadas, que, se năo săo autocráticas, possuem uma forma rígida de atuar, priorizando o Estado, perante o governo; e c) levando consigo a representatividade da religiăo judaica com instituiçôes confessionais, que, se nâo săo teocráticas, pelo menos dăo margem a um autogoverno interno de religiosos. Nấo se constitui em um governo de todos os judeus, mas busca abraçar a maioria das correntes do judaísmo identitário, religioso, cultural e nacional.

Os que năo estăo representados buscam essas mesmas instituiçóes para uma ascensăo, ainda que sempre dificultada. Diante de tal cenário, Israel poderia ser só uma autocracia militar, só uma teocracia religiosa, ou uma democracia pura e laica com maioria de judeus, pensando os extremos mais improváveis. Pois năo constitui sequer uma combinaçâo mista de autocracia, teocracia e democracia. A ideia de Estado judeu dilui esses termos de tal forma que podemos ficar apenas na questâo de categorias de sistemas políticos: liberalismo, nacionalismo e confessionalismo. Essas três definiçôes podem fazer com que vislumbre a imagem de um governo misto pela perspectiva israelense, através do conceito de "Estado judeu".

E aqui cabe verificar algumas tendências: a) de, a partir do liberalismo, Israel desenvolver uma perspectiva de democracia liberal; b) de, a partir do nacionalismo, ter o risco de cair em uma situaçáo de risco, em que um pensamento autoritário cresce, fortalecendo ainda mais o já presente militarismo nas instituiçôes israelenses; e c) de, a partir do confessionalismo, algumas correntes fundamentalistas judaicas sentirem-se à vontade para sujeitar o restante da populaçăo, criando uma forma de governo religioso judaico que dá às costas aos demais cidadâos, podendo acirrar ainda mais os ânimos com a populaçăo nâo-judaica e năo-religiosa.

Ou seja: a ideia de um governo misto aqui existe para atender uma demanda bem específica, bem diferente daquela que Políbio e Maquiavel apontaram para a Roma antiga: para aproximar e unir a maior quantidade de judeus possíveis. Se isso é bom ou ruim, o tempo dirá. A consciência do perigo de um extermínio gera a uniăo de um grande grupo em torno da unificaçăo de um corpo político. No entanto, no caso do Estado de Israel, o equilíbrio de poder náo se dá por uma harmonia entre classes sociais (conforme o pensamento polibiano), mas sim pela reuniâo entre os mais fortes; e dessa reuniăo é gerada uma resultante que propicia o sistema liberal-democrático como um legitimador social. A ideia maquiaveliana de luta entre classes parece mais realista dentro de tal análise. No entanto, năo se trataria de classes sociais, mas 
sim de vertentes culturais: nacionalistas, laicos, religiosos, etc., vindos de fora para dentro, das mais variadas regiōes do mundo. E, nesse sentido, se trata de uma luta cultural pela apropriaçấo do que é "ser judeu" dentro de Israel11. A questâo material de como o Estado foi fundado e é governado, pelos pais fundadores, elite e povo, conceito pensado pelos clássicos, parece bastante diluída nesse caso.

Há, sem dúvida uma forma de hegemonia, que tendeu de uma centro-esquerda para uma centro-direita, conforme o avanço da Guerra Fria e a aproximaçăo de Israel em relaçấo aos EUA (este um exemplo claro do que seria uma forma mista de governo năo apenas em relaçaáo às suas instituiçóes governamentais, como à sua originalidade em construir uma federaçâo para subdividir e distribuir os poderes).

Há, sem dúvida, na perspectiva de conflitos entre Israel e seus vizinhos, a possibilidade de fazer analogias, tal como foi feito já no passado entre Atenas e Esparta (ou a Pérsia). Por ter mais elementos liberais, Israel consegue filtrar mais seus conflitos internos, e canalizar decisóes, de modo a tomar rumos mais resolutos, por exemplo, em uma guerra. Vamos nos lembrar que, em 1948, 1967 e 1973, o país sozinho venceu países que tinham cada um seu próprio objetivo. Nenhum desses países possuía uma sociedade civil tăo forte quanto a israelense. Talvez a libanesa se aproximasse um pouco mais. E governos com sociedade civis fracas, e regimes mais autoritários tendem, nos momentos de se arriscar, a se perder nos humores dos grupos restritos que os governam12. No entanto, há aqui outros fatores para ser analisados. É possível afirmar que a política de alianças de Israel foi mais bem-sucedida que a dos países árabes ao longo da Guerra Fria. E, nesse sentido, enquanto Israel esteve ao lado de uma potência que năo se desintegrou, os EUA, os seus principais adversários (Egito nasserista, Síria, etc.) foram vendo a URSS e o seu bloco se desmanchar. Obviamente, uma aliança coma potência liberal-federalista EUA deu a Israel mais frutos do que com a autocracia stalinista URSS. Mas essa é uma questăo que a área de conhecimento das Relaçóes Internacionais pode responder de maneira mais estruturada.

\section{CONSIDERAÇÕES FINAIS}

Levando em conta o pensamento bobbiano, e o conceito de governo misto para Israel, é possível verificar algo mais próximo daquilo que seria a teoria das elites governantes; perante a definiçăo de que, no fim, sâo as elites quem realmente governa. A questăo seria se essas elites possuem uma forma autocrática ou democrática de governar. E, nesse sentido, năo há uma forma pura de governo. Dentro de uma visâo em que as elites possuem concepçôes democráticas, o sistema político eleitoral e pluripartidário seria um fator que daria a elas o respaldo para a competitividade interna entre elas, sendo, por isso, uma elite propositiva em relaçâo à sua populaçâo. Os setores dessa mesma elite estariam, de tal forma, competindo entre si, tendo um eleitorado popular, sua participaçăo (TOSI, 2016, pp. 89-100).

11 Para năo falar do significado do que significa "ser judeu" em qualquer lugar.

12 O que nâo quer dizer que existisse participaçăo popular nesses países. Apenas que a dinâmica entre Estado e governo era mais restrita. 
Seria assim uma releitura da concepçăo e da definiçăo de governo misto, dessa vez pensando democracia e liberalismo. No caso de Israel, essa visáo leva em conta duas elites hegemônicas: uma leiga, outra religiosa. A primeira se ancora na percepçâo do iminente medo da discriminaçăo, das perseguiçôes, e, no limite, do extermínio, e aposta no nacionalismo enquanto forma de aglutinar judeus em todo o mundo para manter a unidade. Nesse sentido, o sionismo político é a ideologia mais preponderante para tal grupo. Por outro lado, a elite religiosa, levando em conta as mesmas percepçóes, busca na prática da religiăo, no retorno à Terra de Israel (Eretz Yisrael) e na nấo-assimilaçăo, a forma de manutençăo de unidade judaica. O sionismo religioso judaico oferece assim um espaço amplo para tal grupo, que dá suporte a muitos judeus que vâo se tornando religiosos, e optam pela saída cultural. Entre essas duas elites, há uma vertente política, que mantém força entre os leigos e é muito atrativa para os religiosos: o sionismo revisionista. Este possui forte conteúdo nacionalista identitário, e aproveita a questâo da ideia de reivindicar para si toda a Terra de Israel, incluídos os territórios da Cisjordânia e de Gaza.

Aqui podemos observar que o limite dessa forma mista de governo se aproxima, para năo afirmar que ultrapassa a fronteira entre o elitismo democrático, e a hegemonia pura e simples. Pois, a partir do momento em que Israel se define enquanto país do território que ocupa do Mediterrâneo ao Rio Jordăo, que forma democrática poderá assumir? Nesse caso, vamos colocar a seguinte perspectiva: cerca de $50 \%$ da populaçáo será judaica; e os outros $50 \%$ será composta de árabes palestinos. A ideia de elites propositivas poderá derrotada pela de elites impositivas definitivamente.

Ainda atualmente, existe a alegaçâo (correta, diga-se) de que Israel está em uma situaçâo beligerante com alguns de seus vizinhos, o que deixa em suspenso um caminho para uma Israel mais aberta. Tecnicamente, está mantido o Estado de guerra com Síria e Líbano, principalmente por causa das disputas dentro da área das Colinas do Golan. Com os palestinos, ainda năo foi fechado um acordo de paz. Apenas dois países árabes sustentam relaçôes diplomáticas, e mesmo assim, bastante frias: Egito e Jordânia. Existe a ameaça de grupos armados como Hezbollah e Hamas, entre outros. Sem contar com o Irá, inimigo declarado. Será que definir a terra de Israel como sendo o equivalente a todo o Estado ajudará essa situaçăo? Em se levando em conta que Israel é um corpo político isolado na regiăo, năo parece ser uma medida sensata. No longo prazo, na ausência de uma potência aliada, como os EUA, isso poderá ter um alto custo político.

Internamente, o preço a se sacrificar seria o de ter que administrar uma populaçáo que nâo se identifica com tal arranjo institucional. Essa populaçăo tenderia a se tornar majoritária. E isso mina qualquer legitimidade dentro de um regime de sufrágios e representativo, mesmo a partir de uma definiçăo mista de governo. Se fosse realizada uma transferência de populaçóes, algo proposto por uma minoria extremista, haveria um custo ainda pior, pois estaria entre uma das diversas violaçôes dos direitos da pessoa humana. E Israel foi criada justamente para defender a populaçâo judaica de violaçôes dos direitos humanos. Essa, entretanto, é uma discussâo que prossegue dentro da sociedade israelense. Por ora, atuando dentro de seus próprios limites de Estado: populaçóes laicas, leigas e religiosas dentro de um ambiente hostil, em que o país constrói uma representaçăo que pode ser boa para o seu corpo político atual, mas que nem sempre está de acordo com as expectativas de outros países e da conjuntura internacional. 


\section{REFERÊNCIAS BIBLIOGRÁFICAS}

ARISTÓTELES (2004). Política. Sāo Paulo: Editora Nova Cultural.

BOBBIO, Norberto (2001). "O público e Bobbio". In: CARDIM, C.H. (org.). Bobbio no Brasil: Um retrato intelectual. Brasília: UnB; Săo Paulo: Imprensa Oficial, pp. 97-114.

(2000). Teoria geral da política: A filosofia política e as liçōes dos clássicos. Rio de Janeiro: Editora Campus.

(1998). A teoria das formas de governo. Brasília: UnB.

(1993). Liberalismo e democracia. Sâo Paulo: Brasiliense.

e Terra.

(1987). Estado, governo, sociedade: Para uma teoria geral da política. Săo Paulo: Paz

CARDOSO, F.S. (2011/2012). “O direito como sistema: dever de coerência e as antinomias segundo Norberto Bobbio". Revista da Faculdade de Direito da Universidade de Sáo Paulo, v. 106/107, pp. 613-625, jan/dez.

GOLDMANN, Nahum (1984). 0 paradoxo judeu. Săo Paulo: B 'nai B 'rith.

KELSEN, Hans (1992). Teoria geral do direito e do Estado. Săo Paulo: Martins Fontes.

MAQUIAVEL, Nicolau (1994). Comentários sobre a primeira década de Tito Lívio. Brasília: Editora UnB.

MOURA, Danieli V.(2009). "A teoria do ordenamento jurídico de Norberto Bobbio". Âmbito Jurídico, Rio Grande, XII, n. 68, setembro. Disponível em: <http://www.ambito-juridico. com.br/site/?n_link=revista_artigos_leitura\&artigo_id=6751\&revista_caderno=23>. Acesso em jul $20 \overline{17}$.

PINSKY, Jaime (1978). Origens do nacionalismo judaico. Săo Paulo: Editora Hucitec. POLÍBIOS (1996). História. Brasília: Editora UnB.

TOSI, Giuseppe (2016). 10 liçōes sobre Bobbio. Petrópolis: Editora Vozes, 2016. 